\title{
Effect of Fermentation Time on the Physico -Chemical, Nutritional and Sensory Quality of Cassava Chips (Kpo-Kpo Garri) a Traditional Nigerian Food
}

\author{
Nwafor Obi Emmanuel*, Akpomie Olubunmi Olufunmi, Erijo Peace Elohor \\ Department of Microbiology, Delta State University, Abraka, Nigeria \\ Email address: \\ obiomanwafor@yahoo.com (Nwafor O. E.) \\ To cite this article: \\ Nwafor Obi Emmanuel, Akpomie Olubunmi Olufunmi, Erijo Peace Elohor. Effect of Fermentation Time on the Physico -Chemical, \\ Nutritional and Sensory Quality of Cassava Chips (Kpo-Kpo Garri) a Traditional Nigerian Food. American Journal of BioScience. \\ Vol. 3, No. 2, 2015, pp. 59-63. doi: 10.11648/j.ajbio.20150302.16
}

\begin{abstract}
Cassava chips (kpo-kpo garri) popularly consumed in the Niger-Delta Area of Nigeria was produced following fermentation of cassava mash for different time durations. The physico-chemical and nutritional quality of the chips was assessed using standard methods. Sensory quality was also assessed using a trained assessment panel. Results revealed a decrease in $\mathrm{pH}$ from $4.03 \pm 0.00$ at 0 hour fermentation time to $3.40 \pm 0.01$ after 24 hours fermentation and $3.00 \pm 0.00$ after 48hours.Cyanogenic acid content also showed similar trend. Carbohydrate, fibre, ash, protein and moisture contents increased with increase in fermentation time Carbohydrate content increased from $39.10 \pm 0.03 \%$ after Ohour fermentation to $42.50 \pm$ $0.05 \%$ after 24 hours and $43.50 \pm 0.05 \%$ after 48 hours fermentation. For fibre, ash, protein and moisture contents, the changes observed were $1.00 \pm 0.02$ to $1.08 \pm 0.02,1.67 \pm 0.02$ to $1.80 \pm 0.01,1.08 \pm 0.10$ to $3.03 \pm 0.03$ and $6.98 \pm 0.10$ to $9.10 \pm 0.00 \%$ respectively from 0 hour to 24 hours fermentation time. Sensory quality assessment showed that the chips prepared from cassava mash fermented for 24 hours were more acceptable. All the quality changes were significantly different $(\mathrm{P}<0.05)$ considering chips produced from mash of 0 hour and 24 hours fermentations Allowing cassava mash fermentation for a period of 24 hours will therefore, yield cassava chips of better acceptable quality than when no fermentation is allowed to take place and an unnecessarily long period of 48 hours
\end{abstract}

Keywords: Fermentation, Physico-Chemical, Nutritional, Cassava, Traditional, Product

\section{Introduction}

Cassava, (Manihot esculenta-crantz) is a root crop produced in the tropics. Starchy cassava roots are quantitatively the third most important food in the tropics after rice and corn, and are significant sources of calories for over 500 million people world-wide (FAO, 2000). Nigeria is reported to be the highest producer (about 34 million tons) of cassava in the world (FAO, 2006). Nutritionally, cassava contains $62 \%$ water, $35 \%$ carbohydrate, $1 \%$ protein, $0.3 \%$ fat and $1.0 \%$ minerals (Westby, 1991).

In Nigeria, as in most African countries, cassava roots are processed into different products as a means of preservation due to their perishability. These products vary depending on culture of the people they include garri, fufu (akpu), lafun, starch, flour, tapioca and cassava chips commonly called kpo-kpo garri. The processes involve fermentation at various stages of production. Fermentation is known to improve shelf life, texture, taste, aroma, nutritional quality and digestibility. It also leads to lowering of anti-nutrient content of the products (Oyewole and Isah, 2012).

Cassava chips (kpo-kpo garri) are produced in Nigeria particularly in the Niger-Delta Area. It is prepared using a modified process of garri production (Adeyemi and Balogh, 1985) as is an emerging delicacy either eaten dry with edible worm, groundnut or dried fish, soaked in water with addition of sugar or salt and/or milk to taste.

Microorganisms known to be involved in cassava fermentation for cassava chips production are Bacillus subtilis, Leuconostoc citrivorum, Streptococcus sp, Corynebacterium sp, Lactobacillus sp. Others are fungi such as Candida tropicalis, and Geotrichum candidum (Oyewole and Odunfa, 1989; Oyewole and Isah, 2012).

Cassava contains two cyanogenic glycosides, linamarine 
and lataustralin which on hydrolysis to hydrocyanic acid by the enzyme linamarase are hazardous when consumed at certain levels (Kobawila et al, 2005; Ernesto et al, 2000). Microorganisms are able to lower the cyanide content of cassava during fermentation due to their possession of linamarase activity.

Like many other local products, cassava chips are produced at home industry level using methods that vary as there is no standard processing technology particularly with respect to fermentation. This results in products with difference qualities. Marketability of such products therefore, depends on how much the quality of the processed product can be improved particularly with reference to the period of fermentation. Documented information exist on the improved methods for prossesing several cassava products for improved performance as in bikedi and ntoba in Congo (Kuboye, 1988; Kobiwala et al, 2005; Irtwange and Achumba, 2009). There is paucity of information on the methods for improving the quality of cassava chips as produced currently in Nigeria. This study was therefore carried out to assess how varying fermentation time during the production of cassava chips (kpo-kpo garri) can bring about improved quality as a way of increasing product marketability.

\section{Materials and Methods}

\subsection{Processing of Cassava Chips (Kpo-Kpo Garri.)}

The traditional method of garri preparation described by Adeyemi and Balogh (1985) was used with modifications. About $500 \mathrm{~kg}$ of freshly harvested cassava tuber (roots) were peeled and washed with water to remove adhering soil particles. Thereafter, the tubers were milled (by grinding) using a milling machine (Simpy, China). The mash obtained was immediately divided into five portions of $10 \mathrm{~g}$ each. To each portion was added 1litre of clean water, put a jute sack and pressed for dewatering. The jute sack allows for fast easy dripping of water. The content of the first sack was processed immediately after pressing to obtain cassava chips. The remaining four portions were processed after pressing and allowing them to stand at room temperature for $12,24,36$ and 48 hours respectively for fermentation to take place.

Pressed cassava mash was processed into chips by frying (roasting) for between 10-15minutes in a shallow wide hot metal pan (pot) until consistently whitish chips (kpo-kpo garri) were obtained. The chips were removed from the pan using a large spoon with long handle allowed to cool to room temperature $\left(29 \pm 2^{\circ} \mathrm{C}\right)$ before the physico-chemical, nutritional and sensory quality attributes were assessed for the various batches.

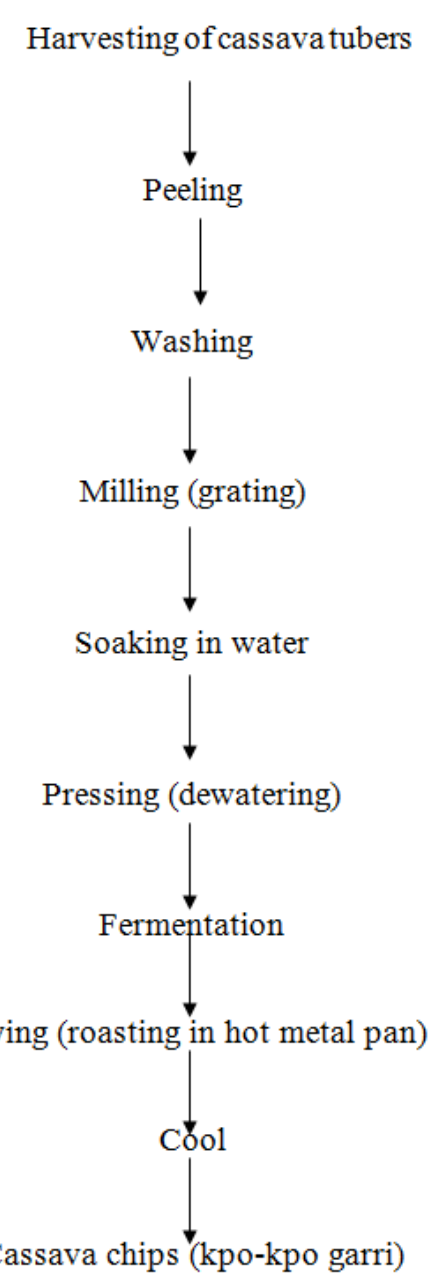

Fig. 1. Flow sheet for the production of cassava chips Adeyemi and Balogh, (1985).

\subsection{Determination of Quality Attributes: All Experiments were Carried Out in Duplicates}

\subsubsection{Hydrogen Ion Concentration (pH)}

The $\mathrm{pH}$ of each of the samples was determined with the aid of a pH meter (Jenway, model 302) after standardizing with buffer at $\mathrm{pH} 4$. The sample in $10 \mathrm{~g}$ quantity was soaked in $50 \mathrm{ml}$ distilled water in a $100 \mathrm{ml}$ beaker for 5 minutes with stirring. Thereafter, the $\mathrm{pH}$ meter electrode was dipped in and readings taken (AOAC, 1990).

\subsubsection{Titratable Acidity (\% Lactic Acid)}

Titratable acidity was determined by dissolving $10 \mathrm{~g}$ of sample in a $100 \mathrm{ml}$ flask containing $50 \mathrm{ml}$ distilled water and stirring for 5 minutes. Sodium hydroxide $(0.1 \mathrm{~N})$ was then titrated against $10 \mathrm{ml}$ of the sample decanted supernatant with phenolphthalein indicator. The result as expressed as percentage lactic acid calculated using the relationship below,

$$
X=\frac{\text { strength of base } x \text { volume of base } x \text { acid factor }}{\text { Volume of sample }}
$$

Strength of base $=0.10 \mathrm{~N}$

Volume of base $=\mathrm{X}$ 
Acid factor $=0.009008$

Volume of sample $=10 \mathrm{ml}$.

\subsubsection{Moisture Content (\%)}

This was determined as a weight loss of water by $5 \mathrm{~g}$ of sample in a weighed watch glass following drying in a vacuum oven (Elothrothermal, England) at $105^{\circ} \mathrm{C}$ to a constant weight. (AOAC 1990)

\subsubsection{Protein Content (\%)}

The method of Lowry et al (1951) was employed. Optical densities (OD) read at 540nm differently for samples using SP30UV spectrophotometer were extrapolated from a standard protein curve to obtain protein contents.

\subsubsection{Ash Content (\%)}

Ash content was determined by the method of (AOAC, 1990). The samples were burned on a bursar burner and charred material was incinerated in an electronic muffle furnace (Model 0508-1, Technol and Technol, Texas, USA) equipped with pyrometer temperature indicator of $550^{\circ} \mathrm{C}$ to obtain a whitish grey ash. The ash so obtained was allowed to cool in a desiccator to room temperature $\left(29 \pm 2^{\circ} \mathrm{C}\right)$, weighed and percentage ash content estimated from the relationship below

$$
\% \text { ash content }=\frac{\text { weight of dish }+ \text { sample }- \text { weight of dish }+ \text { ash }}{\text { weight of dish }+ \text { sample }} \times \frac{100}{1}
$$

\subsubsection{Fat Content}

Soxhlet method as described by Meloaan and Pomeranz (1973) was employed. The extraction as carried out with petroleum ether (BDH, England) at a temperature range of 40 - 60oC for 5 minutes, followed by oven drying for 30 minutes at $100 \mathrm{oC}$ for the solvent to evaporate, allowed to cool and weighed..

\subsubsection{Fibre Content (\%)}

To determine fibre content, the sample oven weight was estimated as well as the weight after ashing. Fibre content was calculated as the ratio the difference between the two values above to the sample weight (AOAC, 1990).

\subsubsection{Hydrocyanic Acid (HCN) Content ( $\mathrm{mg} / \mathrm{g}$ )}

Alkaline titration method was used to estimate the amount of hydrocyanic acid in milligram per gram of sample (A0AC, 1990).

\subsubsection{Sensory quality Assessment}

This was carried out using the parameters of taste, colour (appearance) aroma (flavor), mouth feel and swelling index using a 9 - point hedonic scale $(1=9,9=1)$ as described by Larmond (1977). A ten (10) member panel made up of trained personnel was used to score the various parameters.

\subsubsection{Statistical Analysis of Data}

Data obtained were subjected to statistical analysis of mean, standard deviation and analysis of variance (ANOVA). The significant value was determined by $t$ - distribution test using appropriate computer software.

Table 1. Effect of fermentation time on physico-chemical and nutritional quality of Cassava chips (kpo-kpo garri)

\begin{tabular}{|c|c|c|c|c|c|}
\hline \multirow{2}{*}{ Parameters } & \multicolumn{5}{|c|}{ Fermentation time (h) } \\
\hline & $\mathbf{0}$ & 12 & 24 & 36 & 48 \\
\hline $\mathrm{pH}$ & $4.03 \pm 0.00$ & $3.80 \pm 0.01$ & $3.40 \pm 0.00$ & $3.00 \pm 0.01$ & $3.0 \pm 0.00$ \\
\hline fibre Content (\%) & $1.00 \pm 0.02$ & $1.06 \pm 0.02$ & $1.08 \pm 0.02$ & $1.20 \pm 0.03$ & $1.30 \pm 0.02$ \\
\hline TA $(\%)$ & $0.01 \pm 0.00$ & $0.04 \pm 0.00$ & $0.04 \pm 0.00$ & $0.06 \pm 0.01$ & $0.06 \pm 0.01$ \\
\hline Moisture Content (\%) & $6.98 \pm 0.10$ & $8.90 \pm 0.04$ & $9.10 \pm 0.00$ & $8.60 \pm 0.01$ & $9.50 \pm 0.02$ \\
\hline Ash (\%) & $1.67 \pm 0.02$ & $1.64 \pm 0.02$ & $1.80 \pm 0.01$ & $1.86 \pm 0.02$ & $1.90 \pm 0.02$ \\
\hline Fat $(\%)$ & $2.10 \pm 0.02$ & $2.90 \pm 0.10$ & $3.10 \pm 0.02$ & $2.20 \pm 0.01$ & $2.00 \pm 0.03$ \\
\hline $\mathrm{CHO}(\%)$ & $39.10 \pm 0.03$ & $40.50 \pm 0.15$ & $42.50 \pm 0.05$ & $42.60 \pm 0.05$ & $42.60 \pm 0.04$ \\
\hline $\mathrm{HCN}(\mathrm{mg} / \mathrm{g})$ & $3.71 \pm 0.01$ & $2.10 \pm 0.02$ & $1.60 \pm 0.01$ & $1.40 \pm 0.10$ & $1.30 \pm 0.10$ \\
\hline
\end{tabular}

Note $:$ Each value is the overall mean $\pm \mathrm{SD}$ for duplicate determinations $. \mathrm{TA}=$ titratable acidity, $\mathrm{CHO}=$ carbohydrate, $\mathrm{HCN}=$ hydrogen cyanide

Table 2. Effect of fermentation time on sensory quality of Cassava chips (kpo-kpo garri).

\begin{tabular}{|c|c|c|c|c|c|c|}
\hline \multirow{2}{*}{ Time (h) } & \multicolumn{6}{|c|}{ Sensory quality attributes } \\
\hline & Taste & Colour & Aroma & Swelling index & Mouth feel & Overall acceptability \\
\hline 0 & $3.20 \pm 0.60$ & $5.40 \pm 0.74$ & $4.80 \pm 0.70$ & $5.40 \pm 0.80$ & $6.60 \pm 0.60$ & $6.40 \pm 0.66$ \\
\hline 12 & $5.90 \pm 0.64$ & $6.00 \pm 0.71$ & $5.40 \pm 0.70$ & $6.00 \pm 0.80$ & $6.80 \pm 0.69$ & $6.90 \pm 0.60$ \\
\hline 24 & $7.60 \pm 0.80$ & $7.60 \pm 0.71$ & $7.40 \pm 0.80$ & $7.60 \pm 0.76$ & $7.30 \pm 0.65$ & $7.65 \pm 0.70$ \\
\hline 36 & $7.00 \pm 0.84$ & $7.20 \pm 0.72$ & $7.20 \pm 0.72$ & $7.30 \pm 0.70$ & $7.00 \pm 0.60$ & $7.10 \pm 0.06$ \\
\hline 48 & $6.90 \pm 0.74$ & $6.80 \pm 0.72$ & $6.80 \pm 0.68$ & $7.00 \pm 0.68$ & $7.00 \pm 0.50$ & $6.80 \pm 0.70$ \\
\hline
\end{tabular}

Note: Each value is the overall mean \pm SD for duplicate determinations. 


\section{Results}

The results of the changes in physico-chemical and nutritional quality of cassava chips obtained following fermentation of cassava mash for $6,12,36$, and 48 hours are presented in Table I.

There was a decrease in $\mathrm{pH}$ values from $4.03 \pm 0.00$ for product obtained from zero $(0 \mathrm{~h})$ hour fermentation to $3.40 \pm 0.00$ and $3.00 \pm 0.00$ for product obtained after 24 hours and 48 hours respectively. Changes in fermentation time influenced the fibre content which showed an increase from zero hour $(1.00 \pm 0.02)$ up to $1.08 \pm 0.02$ after 24 hours and $1.30 \pm 0.02$ after 48 hour fermentation period. Other parameters such as titratable acidity, moisture, protein, ash and carbohydrate contents also increased with increase in fermentation time.

On the contrary, there was a decrease in the $\mathrm{HCN}$ with increasing fermentation period from $3.71 \pm 0.01 \mathrm{mg} / \mathrm{g}$ at 0 hour fermentation time to $2.10 \pm \mathrm{mg} / \mathrm{mg}$ after 24 hours and $1.30 \pm$ $0.10 \mathrm{mg} / \mathrm{g}$ after 48 hours fermentation of cassava mash.. In all the cases, the changes as affected by fermentation time are significantly different $(\mathrm{P}<0.05)$ when compared with the result at 0 hour fermentation time.

The effect of duration of fermentation on sensory (organoleptic) quality of cassava chips is presented in Table 2 Considering the attribute of taste, there is a significant difference $(\mathrm{p}<0.05)$ as seen in the scores which were lowest at Ohour when no fermentation was involved and higher after 24 hours fermentation. Further increase in fermentation time did not result in significant $(\mathrm{p}<0.05)$ increase in scores recorded. The trends with other parameters are the same. Furthermore product obtained after fermentations of cassava mash for 24 hours showed more acceptability considering the taste, colour, flavour, swelling index and mouth feel. This was followed by chips from a longer fermentation time of 36hours.

\section{Discussion}

The changes in physico-chemical, nutritional and sensory quality of cassava chips (kpo-kpo garri) as a result of differences in fermentation times of the mash is an indication that fermentation plays a significant role in the product quality. This is in agreement with some earlier reports (Okafor, 1977; Onyekwere et al, 1983; Irtwange and Achumba, 2009).

There was a reduction in $\mathrm{pH}$ with time of fermentation (Table I). This suggests the production of organic acids during fermentation likely due to lactic acid bacteria which are known to be predominant during cassava mash fermentation. This assertion is in line with reports of Ogiehor, (2002) and Kobawila et al., ( 2005). The pH reduction with concomitant increase in titratable acidity may equally be due to activities of microorganisms prompted by the prevailing temperature as has been earlier reported (Onwuaman et al, 2002; Chelule et al, 2010). Oshuntogun and Abaoba (2004) opined that microorganisms release organic acids during fermentation leading to an increase TA and reduction in $\mathrm{pH}$ with time. There was an increase in each of protein, ash and carbohydrate contents with increase in fermentation. It is thought to be due to the action of fermenting microorganisms This is in line with the reports of Eka, (1986); Tyleskar et al., (1992). They had suggested that microbial fermentation is linked to break down of components of their substrates thereby releasing bound nutrients Similar result has also beeb reported (Nwafor and Ogiehor, 2004). The ability of microorganisms to synthesize amino acids may be the reason for the increase in protein content with increasing fermentation time. It corroborates the earlier report by Jokotagha and Amoo (2002). A reduction in fat content with fermentation time up till after 48 hours can be attributed to the influence of increasing temperature of fermentation. Temperature is known to affect the physical characteristics of fat foods (Irtwange and Achumba, 2009). It has been established that as temperature increases, the solid fat index of some foods decreases (Werss, 1983). Temperature may therefore be the reason for the rate of decrease in fat content of kpo-kpo garri recorded in this study.

The recorded decrease in $\mathrm{HCN}$ content may be due to various activities taking place during cassava mash fermentation. Fermentation is a detoxification process (Okafor, 1977, Okafor and Ejiofor, 1986, Agbor-Egbe and Mbome 2006 ). Most of the organisms involved in cassava mash fermentation are also known to possess linamarase activity, thereby ensuring elimination of cyanogenic glycosides as earlier reported by Bokanga (1995). The high temperature at which kpo-kpo garri is roasted also contributes to the reduction in HCN content. This agrees with the report of Menser and Smolnik (1980).

Acceptability scores show that cassava chips obtained following 24 hour fermentation was most acceptable. It has been reported that the taste effect of garri improves due to enhanced production and retention of desired organic acids and aroma (Onwuamanam et al, 2011). It is an indication that proper fermentation time of 24 hours may conserve and contribute to the properties responsible for enhanced sensory quality of kpo-kpo garri.

\section{References}

[1] Adeyemi. M.O. and Balogh, E. (1985). Processing of indigenous fermented foods. Nigerian Food Journal 3:31-34

[2] Agbor-Egbe, T. and Mbome, L.I. (2006). The effect of processing Techniques in reducing cyanogen levels during the production of some Cameroonian cassava foods. Journal of Food Comparative analysis 19:354-363

[3] AOAC (1990). Official Method of Analysis. Association of Official Analytical Chemists (edn) Washington DC p 596

[4] Bokanga, M. (1995). Biotechnology and Cassava processing in Africa. Food Technology 49(1):86-90 
[5] Eka, O.U. (1986). Studies on the fermentation of cassava. Some enzymes of microorganisms in the fermentation liquor and the effect of fermentation on nutrient status of cassava products. West African Journals of Botany and Chemistry 31(1-4) 3-12

[6] Ernesto, M., Cardoso, A.P., Cliff, J. and Brabury, J.A. (2000). Cyanogenes in cassava flour and roots and urinary thiocyanate concentration in mozaribique. Journal of Food Composition analysis 13: 1-12

[7] FAO (2000).Food and Agricultural organization of the United Nations: Championing the cause of cassava file/A/championing cause of cassava $\mathrm{Htm}$

[8] FAO (1970). Food and Agricultural organization yearBook. FAO Rome, Italy Pp 215-225

[9] Westby, A. (1991). Strategies for research into the mechanisms of cyanide reduction during the fermentation of cassava. Food laboratory News 7:24-28

[10] Irtwange, S.V. and Achumba, O. (2000). Effect of the duration of fermentation on the quality of Garri. Current Research Journal of Biological Science 1(3):150-154

[11] Jokotagha, O.A. and Amoo, I.A. (2012). Effect of fermentation on the nutritive value of Aspergillus niger and Aspergillus fumigatus fermented Hura crepitans seed flour. Journal of Laboratory Science 1:48-51

[12] Kobawila, S.C, Louembe, D. Keleke, S., Hounhouigan, J. and Gamba, C. (2005). Reduction of the cyanide content during fermentation of cassava roots and leaves to produce bikedi and ntoba mbadi, two food products from Congo. African Journal of Biotechnology 4 (7):689-696

[13] Kuboye, A.O. (1988). Microbial examination of roots and tubers food products. International Training Workshop on improvement of the quality of roots and tubers crops. FIIRO Technical Bulletin series No.4 pp 10-15

[14] Larmond, E.I. (1977). Laboratory methods for sensory evaluation of foods. Research Institute, Ottawa, Canada Department Agriculture publication 1637
[15] Lowry, O.H., Niatu, J.R. and Farr, A.L. (1951). Protein measurement with folin-phenol reagent Journal of Biological Chemistry 199:265-275

[16] Ogiehor, I.S. (2002). Extension of shelf life of garri by combination of preservation factors. Ph.D Thesis, University of Benin, Benin-City pp 162.

[17] Ogiehor, I.S. and Nwafor, O.E. (2004). Associated microbiological, Biochemical and Chemical quality changes in zobo beverage produced from Hibiscus sabdariffa Linn. Nigerian Annals of Natural Science 1(2):1-10

[18] Chelule, P.K., Mbogwa, H.P. Carries, S. and Ggaleni, N. (2010). Lactic acid fermentation improves the quality of Gmahewu, a traditional South African Maize-based porridge. Food Chemistry 122(3):656-661

[19] Okafor, N. (1977). Microorganisms associated with cassava fermentation for garri production. Journal of Applied Bacteriology 42(2):279-294

[20] Okafor, N. and Ejiofor, A.O. (1986). Rapid detroxification of cassava fermentation for garri production following inoculation with a yeast simultaneously producing linamarase and analyse. Process Biotechnology Internation 25:82-85

[21] Onwuamanam, C.I., Iwauno, J.O. Ihediohanma, N.C and Barber, L. (2010)., cyanide reduction, functional and sensory quality of garri as affected by $\mathrm{pH}$, temperature and fermentation time. Pakistan Journal of Nutrition 9 (10):980956

[22] Oyewole, O.A. and Isah, P. (2012). Locally fermented foods in Nigeria and their significance to National economy: a Review. Journal of recent Advances in Agriculture 1(4):92-102

[23] Oyewole, O.A. and Odunfa, S.A. (1989). Microbiological studies on cassava fermentation for Lafun production. Journal of Food Microbiology 5:125-133

[24] Tyllerskar, T., Barea, M. Bikangi, N. Cooke, R. Poulen, N.H. and Bostling, H. (1992). Cassava cyanogens and Konzo found in African. Lancet 339:208-211 